\title{
CTD Nuclear Envelope Phosphatase 1
}

National Cancer Institute

\section{Source}

National Cancer Institute. CTD Nuclear Envelope Phosphatase 1. NCI Thesaurus. Code C102890.

CTD nuclear envelope phosphatase 1 (244 aa, $28 \mathrm{kDa}$ ) is encoded by the human CT DNEP1 gene. This protein plays a role in the dephosphorylation and regulation of fatty acid phosphatase proteins. 